\title{
Passive smoking by pregnant women and fetal growth
}

Hiroshi Ogawa, Suketami Tominaga, Kohji Hori, Keiichi Noguchi, Izumi Kanou, Mikihiko Matsubara

\begin{abstract}
Study objective-The aim was to investigate the effect of passive smoke exposure during pregnancy on fetal growth in the Japanese population.

Design-The study comprised a community based interview and clinical survey of pregnant women in Aichi Prefecture, Japan.
\end{abstract}

Setting-Participants attended for delivery at 146 private and public practices and hospital clinics in the Prefecture.

Subjects-Participants were 6831 women who delivered a live singleton without malformation during the three consecutive months from June 1987, and comprised about $34 \%$ of total deliveries in the Prefecture during the period.

Measurements and main results-35\% of the women had been exposed passively to cigarette smoke for $2 \mathrm{~h}$ or more per day at home, in the work place, or in other places during pregnancy. At this level of passive exposure among non-smoking women with term deliveries ( $\geqslant 37$ weeks), a small effect on fetal growth was observed; mean birth weight was reduced by $10.8 \mathrm{~g}$, and the relative risk of growth retardation $(<2500 \mathrm{~g}$ birth weight) was $1 \cdot 0(95 \% \mathrm{CI}: 0 \cdot 7-1 \cdot 5)$, after adjusting age, parity, height, alcohol drinking, occupation, and gestation.

Conclusions-The results suggest that the reduction of fetal growth associated with passive smoke exposure during pregnancy may be small in Japanese population.

During the past 30 years, extensive evidence on the effect of maternal smoking during pregnancy on fetal growth has been accumulated. The research can be summarised as showing an approximate $200 \mathrm{~g}$ reduction of birth weight and a 1.6 to 2.2 relative risk of low birth weight (under $2500 \mathrm{~g}$ ) for babies born to women who smoke during pregnancy, when compared with babies born to comparable women who do not smoke. ${ }^{1}$ The most likely explanation for the adverse effects of smoking is that it causes fetal hypoxia resulting from the increased carboxyhaemoglobin level, attenuated blood oxygen unloading, and vasoconstriction of maternal blood supply to the placenta. $^{2}$

Pregnant women who do not smoke may also be at risk from passive smoking at home, the work place, and other places. The concentrations of carbon monoxide and nicotine are 2.5 and 2.7 times higher respectively in sidestream than in mainstream smoke. ${ }^{1}$ An increase in the concentration of cotinine was observed in the urine of non-smokers who live with smokers, ${ }^{34}$ and in the amniotic fluid of non-smoking pregnant women chronically exposed to tobacco smoke. $^{5} 6$

The evidence from epidemiological investigations on the effect of passive smoking on fetal growth is inconsistent. Several studies in the USA from the early 1960 s to early 1970 s failed to find any relation between paternal smoking and birth weight. ${ }^{7-10}$ More recent studies showed a significant relation of low birth weight to the amount of paternal smoking, ${ }^{11}$ duration of tobacco smoke exposure, ${ }^{12}$ and serum cotinine concentration of non-smoking mothers. ${ }^{13}$ However, a study in China showed no effect of paternal smoking. ${ }^{14}$

The risk from passive smoking is a serious problem in Japan, and women of reproductive age are highly likely to be exposed to cigarette smoke at home and in the work place. The prevalence of cigarette smokers among persons aged 20 to 39 years was $70 \%$ for males and $16 \%$ for females in Japan in 1986 (unpublished observations from a nationwide survey on the prevalence of cigarette smokers conducted by Japan Tobacco Industry Co). The rate of employed persons in this age group was $93 \%$ for males and $58 \%$ for females in $1985 .{ }^{15}$ These figures were enough to warrant concern about the risk. A recent study in Japan reported a rather small effect of paternal smoking on growth retardation (gestation $\geqslant 37$ weeks and birthweight $<2500 \mathrm{~g}$ ) of babies from nonsmoking mothers; crude relative risk was 1.2 $(90 \%$ CI $0 \cdot 8-1 \cdot 5) .{ }^{16}$ In the present study we aimed to examine the effect of passive smoke exposure among pregnant women on fetal growth in the Japanese population.

\section{Methods}

Obstetricians in Aichi Prefecture, Japan, who are members of the Aichi Society of Obstetricians and Gynaecologists, were invited to participate in the study, and 146 private or public practices and hospital clinics participated. The Society sent semistructured questionnaire format sheets to the participating institutions. Brief instructions on the procedure for information collection were given on each sheet. Women who underwent prenatal care at these facilities were interviewed before or after delivery by physicians, midwives, or nurses. The responses were recorded on the format sheet. Information gathered on cigarette smoke exposure included smoking by women and their husbands before and after pregnancy, and the average length of passive smoke exposure during pregnancy per day at home, the work 
place, and other places. Information on alcohol drinking and occupation during pregnancy was also obtained at the interview. Data regarding pregnancy, delivery, and other clinical items were

Table I Maternal cigarette smoke exposure during pregnancy

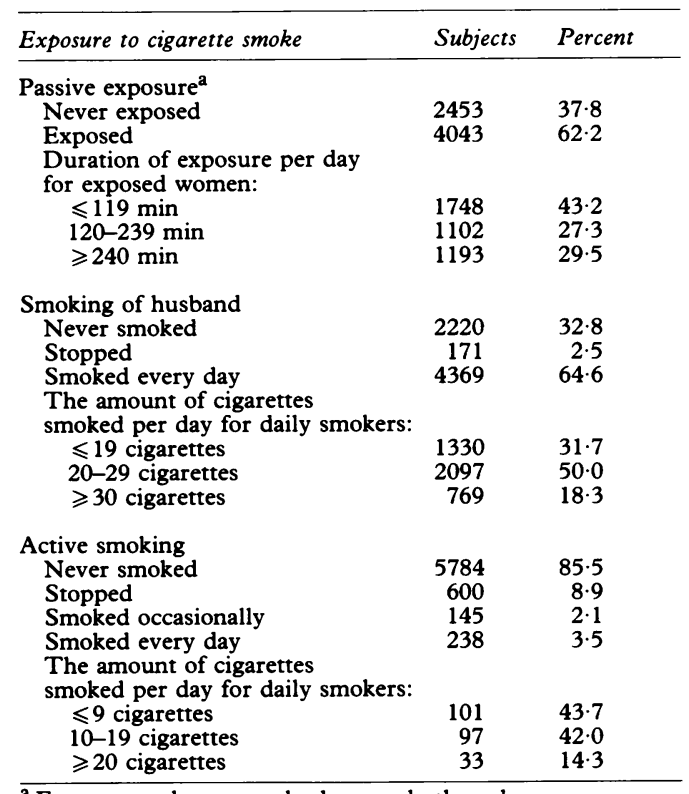

${ }^{\mathrm{a}}$ Exposure at home, work place, and other places
Table II Maternal characteristics by cigarette smoke exposure during pregnancy

\begin{tabular}{|c|c|c|c|c|c|}
\hline \multirow[b]{2}{*}{ Characteristics } & \multicolumn{5}{|l|}{ Exposure } \\
\hline & $\begin{array}{l}\text { Active: } \\
\text { Passive: }\end{array}$ & $\begin{array}{l}- \\
- \\
\end{array}$ & + & $\begin{array}{l}+ \\
-\end{array}$ & $\begin{array}{l}+ \\
+ \\
\end{array}$ \\
\hline $\begin{array}{l}\text { The number of subjects } \\
(\% \text { by exposure status })\end{array}$ & & $\begin{array}{l}4018 \\
(62 \cdot 4)\end{array}$ & $\begin{array}{l}2076 \\
(32 \cdot 2)\end{array}$ & $\begin{array}{l}144 \\
(2 \cdot 2)\end{array}$ & 201 \\
\hline $\begin{array}{c}\text { Age (years) } \\
\leqslant 19 \\
20-24 \\
25-29 \\
30-34 \\
\geqslant 35\end{array}$ & & $\begin{array}{r}0 \cdot 6 \\
14 \cdot 6 \\
52 \cdot 3 \\
26 \cdot 3 \\
6 \cdot 2\end{array}$ & $\begin{array}{r}1 \cdot 3 \\
22 \cdot 5 \\
50 \cdot 9 \\
20 \cdot 5 \\
4 \cdot 8\end{array}$ & $\begin{array}{r}3 \cdot 5 \\
17 \cdot 5 \\
41 \cdot 3 \\
27 \cdot 3 \\
10 \cdot 5\end{array}$ & $\begin{array}{r}8 \cdot 0 \\
24 \cdot 6 \\
41 \cdot 7 \\
19 \cdot 1 \\
6 \cdot 5\end{array}$ \\
\hline $\begin{array}{l}\text { Mean } \\
\text { SD }\end{array}$ & & $\begin{array}{r}28 \cdot 2 \\
3 \cdot 8 \\
t\end{array}$ & $\begin{array}{r}27 \cdot 3 \\
3 \cdot 9 \\
8 \cdot 16 \dagger\end{array}$ & $\begin{array}{r}28 \cdot 3 \\
4 \cdot 5\end{array}$ & $\begin{aligned} & 26 \cdot 7 \\
& 4 \cdot 8 \\
&= 3 \cdot 13 \dagger\end{aligned}$ \\
\hline $\begin{array}{c}\text { Height }(\mathrm{cm}) \\
\leqslant 149 \\
150-154 \\
155-159 \\
160-164 \\
\geqslant 165\end{array}$ & & $\begin{array}{r}6 \cdot 0 \\
28 \cdot 9 \\
38 \cdot 0 \\
22.5 \\
4 \cdot 6\end{array}$ & $\begin{array}{r}5 \cdot 7 \\
28 \cdot 8 \\
36 \cdot 3 \\
24 \cdot 3 \\
4 \cdot 9\end{array}$ & $\begin{array}{r}7 \cdot 3 \\
35 \cdot 0 \\
27 \cdot 0 \\
23 \cdot 4 \\
7 \cdot 3\end{array}$ & $\begin{array}{r}5 \cdot 7 \\
24 \cdot 7 \\
36 \cdot 6 \\
28 \cdot 4 \\
4 \cdot 6\end{array}$ \\
\hline $\begin{array}{l}\text { Mean } \\
\text { SD }\end{array}$ & & $\begin{array}{r}156 \cdot 3 \\
4 \cdot 8\end{array}$ & $\begin{array}{r}156 \cdot 5 \\
4 \cdot 9 \\
1 \cdot 50\end{array}$ & $\begin{array}{r}156 \cdot 4 \\
5 \cdot 1\end{array}$ & $\begin{aligned} & 157 \cdot 1 \\
& 4 \cdot 8 \\
= & 1 \cdot 37\end{aligned}$ \\
\hline $\begin{array}{l}\text { Parity } \\
\text { Nulliparous } \\
\text { Multiparous }\end{array}$ & & $\begin{array}{l}36 \cdot 3 \\
63 \cdot 7 \\
\chi^{2}\end{array}$ & $\begin{array}{r}48 \cdot 1 \\
51 \cdot 9 \\
78 \cdot 72 \dagger\end{array}$ & $\begin{array}{l}32 \cdot 2 \\
67 \cdot 8\end{array}$ & $\begin{aligned} & 38 \cdot 6 \\
& 61 \cdot 4 \\
= & 1 \cdot 48\end{aligned}$ \\
\hline $\begin{array}{l}\text { Alcohol } \\
\text { Never } \\
\text { Stopped } \\
\text { Occasionally } \\
\text { Every day }\end{array}$ & & $\begin{array}{l}71 \cdot 3 \\
16 \cdot 1 \\
12 \cdot 2 \\
0 \cdot 5 \\
\quad \chi^{2}\end{array}$ & $\begin{array}{r}61 \cdot 5 \\
21 \cdot 9 \\
16 \cdot 2 \\
0 \cdot 4 \\
61 \cdot 16 \dagger\end{array}$ & $\begin{array}{r}50 \cdot 7 \\
23 \cdot 6 \\
22 \cdot 2 \\
3 \cdot 5\end{array}$ & $\begin{aligned} & 46.3 \\
& 23.9 \\
& 25.9 \\
& 4.0 \\
&=0.86\end{aligned}$ \\
\hline $\begin{array}{l}\text { Occupation } \\
\text { Never worked } \\
\text { Stopped to work } \\
\text { Continued/started to work }\end{array}$ & & $\begin{array}{l}66 \cdot 1 \\
15 \cdot 0 \\
18 \cdot 9 \\
\quad \chi^{2}\end{array}$ & $\begin{array}{r}41 \cdot 8 \\
20 \cdot 4 \\
37 \cdot 7 \\
352 \cdot 0 \dagger\end{array}$ & $\begin{array}{l}53 \cdot 2 \\
22 \cdot 4 \\
24 \cdot 5\end{array}$ & $\begin{aligned} & 47 \cdot 0 \\
& 20 \cdot 2 \\
& 32 \cdot 8 \\
= & 2 \cdot 80\end{aligned}$ \\
\hline $\begin{array}{l}\text { Smoking of husband } \\
\text { Never/stopped } \\
\text { Every day }\end{array}$ & & $\begin{array}{l}47 \cdot 2 \\
52 \cdot 8 \\
\chi^{2}\end{array}$ & $\begin{array}{r}18 \cdot 8 \\
81 \cdot 2 \\
467 \cdot 57 \dagger\end{array}$ & $\begin{array}{r}18 \cdot 4 \\
81 \cdot 6 \\
\chi\end{array}$ & $\begin{array}{r}5 \cdot 6 \\
94 \cdot 4 \\
=13 \cdot 81 \dagger\end{array}$ \\
\hline
\end{tabular}

Active exposure: + (Occasionally/every day), - (Never/stopped)

Passive exposure: $+(\geqslant 2 \mathrm{~h}),-(<2 \mathrm{~h})$

$+\mathrm{p}<0.01$ transferred from medical records to the format sheets. Between June 1 and August 31, 1987, 7313 women interviewees delivered (estimated as $36.1 \%$ of the total deliveries in Aichi Prefecture during the period). Of these, 6831 women delivered a live singleton without malformation. These women and babies were the study subjects. The associations between passive smoking and birth weight and the prevalence of growth retardation $(<2500 \mathrm{~g}$ birth weight in $\geqslant 37$ weeks gestational age) were examined. Multiple linear regression and binary multiple logistic regression were used to adjust for the possible effects of confounding factors. ${ }^{17} 18$ In the categorical statistical analysis, passive smoking was defined as exposure to other persons' cigarette smoke for at least $2 \mathrm{~h}$ per day at home, the work place, and other places, as in a previous study. ${ }^{12}$

\section{Results}

\section{CIGARETTE SMOKE EXPOSURE}

The rate of passive exposure to cigarette smoke was $62 \cdot 2^{\circ}{ }_{0}$ for at least $1 \mathrm{~min}$ per day, and $35.3^{\circ}{ }_{0}$ for at least $2 \mathrm{~h}$ per day, as shown in table I. Mean exposure time for the exposed women was $3 \cdot 1 \mathrm{~h}$ per day. The distribution of overall exposure time by place was $57 \cdot 1^{\circ}{ }_{0}$ at home, $35 \cdot 2^{\circ}{ }_{0}$ at the work place, and $7 \cdot 7 \%$ for other places. The prevalence of smoking among husbands during pregnancy was $64 \cdot 6^{\circ}{ }_{0}$. The mean number of cigarettes smoked by them was 19.6 per day, which was not different from 20.3 per day before pregnancy. About $30^{\circ}{ }_{0}$ of women whose husbands smoked during pregnancy were not exposed at all to cigarette smoke at home, and about $13^{\circ}{ }_{0}$ of women whose husbands never smoked were exposed at home. Only about $6^{\circ}{ }_{0}$ of women smoked cigarettes during pregnancy. More than half of the women who had been smoking before pregnancy stopped smoking after becoming pregnant. Mean gestation at the time of stopping smoking was 8.2 weeks. Mean consumption of cigarettes for daily smokers was 10.2 per day, which was significantly less than the $13 \cdot 7$ per day before pregnancy $(p<0.01)$.

\section{CHARACTERISTICS OF PASSIVE SMOKERS}

Table II shows that women who were exposed to smoke tended to be young and nulliparous, to drink alcohol, to be employed, and to have smoking husbands, compared with those who were not exposed. This tendency was significant among women who were non-smokers $(p<0.01)$. Therefore, these characteristics were included as possible confounding factors in the multivariate analysis of the association between passive smoking and fetal growth.

MATERNAL EXPOSURE TO CIGARETTE SMOKE AND FETAL GROWTH

There was a small but statistically significant decrease in birth weight from passive smoke exposure in mothers who had never smoked, while no significant change was observed in smoking mothers who stopped or continued to smoke, as shown in table III. The crude relative risk of growth retardation from passive smoke exposure was almost unity for mothers who had never smoked and also for smoking mothers who 
Table III Mean birth weights and growth retardation rates by maternal cigarette smoke exposure during pregnancy. Infants with gestational age less than 37 weeks excluded

Table IV Mean birth weight and growth retardation rate by passive smoke exposure in mothers who had never smoked; $n=5336$. Infants with gestational age less than 37 weeks excluded

\begin{tabular}{|c|c|c|c|c|c|c|c|}
\hline \multirow{2}{*}{$\begin{array}{l}\text { Exposure }{ }^{\mathbf{a}} \\
{[\text { Active } \cdot \text { Passive }]} \\
\end{array}$} & \multirow{2}{*}{$\begin{array}{l}\text { Number of } \\
\text { subjects }\end{array}$} & \multicolumn{3}{|c|}{ Birth weights $(g)$} & \multicolumn{3}{|c|}{ Growth retardation } \\
\hline & & Mean & Difference & $(95 \% C I)$ & Rate $(\%)$ & $R R$ & $(95 \% C I)$ \\
\hline $\begin{array}{l}{[-\cdot-]} \\
{[-\cdot+]} \\
{[ \pm \cdot-]} \\
{[ \pm \cdot+]} \\
{[ \pm \cdot-]} \\
{[+\cdot+]}\end{array}$ & $\begin{array}{r}3606 \\
1730 \\
243 \\
275 \\
138 \\
183\end{array}$ & $\begin{array}{l}3183 \\
3159 \\
3140 \\
3155 \\
3108 \\
3113\end{array}$ & $\begin{array}{r}-24^{\star} \\
15 \\
5\end{array}$ & $\begin{array}{r}(2-47) \\
(-50-81) \\
(-79-89)\end{array}$ & $\begin{array}{l}2 \cdot 8 \\
3 \cdot 0 \\
2 \cdot 1 \\
3 \cdot 6 \\
4 \cdot 3 \\
4 \cdot 4\end{array}$ & $\begin{array}{l}1.0 \\
1.1 \\
1.0 \\
1.8 \\
1.0 \\
1.0\end{array}$ & $\begin{array}{l}(0 \cdot 8-1 \cdot 5) \\
(0 \cdot 6-5 \cdot 3) \\
(0 \cdot 3-3 \cdot 0)\end{array}$ \\
\hline
\end{tabular}

Active exposure: + (smoked occasionally or every day); \pm (stopped smoking); - (never smoked) Passive exposure: + (exposed $2 \mathrm{~h}$ or more a day); - (exposed less than $2 \mathrm{~h}$ a day) $\mathbf{R} \mathbf{R}=$ relative risk $\star \mathrm{p}<0.05$

\begin{tabular}{|c|c|c|c|c|c|c|c|}
\hline \multirow{2}{*}{$\begin{array}{l}\text { Passive exposure } \\
\text { to cigarette } \\
\text { smoke per day }\end{array}$} & \multirow[b]{2}{*}{ Subjects } & \multicolumn{3}{|c|}{ Birth weight ( $g$ ) } & \multicolumn{3}{|c|}{ Growth retardation } \\
\hline & & Mean & Difference & $(95 \% C I)$ & Rate $(\%)$ & $R R$ & $(95 \% C I)$ \\
\hline $\begin{array}{l}\text { Never exposed } \\
<2 \mathrm{~h} \\
2-3 \mathrm{~h} \\
\geqslant 4 \mathrm{~h}\end{array}$ & $\begin{array}{r}2149 \\
1457 \\
859 \\
871\end{array}$ & $\begin{array}{l}3176 \\
3193 \\
3166 \\
3152\end{array}$ & $\begin{array}{r}17 \\
-10 \\
-24\end{array}$ & $\begin{array}{r}(-9-42) \\
(-19-41) \\
(-5-54)\end{array}$ & $\begin{array}{l}2 \cdot 9 \\
2 \cdot 7 \\
2 \cdot 9 \\
3 \cdot 1\end{array}$ & $\begin{array}{l}1.0 \\
0.9 \\
1.0 \\
1.1\end{array}$ & $\begin{array}{l}(0.6-1 \cdot 4) \\
(0.6-1 \cdot 6) \\
(0.7-1.7)\end{array}$ \\
\hline
\end{tabular}

$\mathrm{RR}=$ relative risk

continued to smoke. For those who stopped smoking, the risk was rather high, but not significant. Table IV shows a more detailed analysis of the effect on fetal growth for mothers who had never smoked. No statistically significant reduction of birth weight was observed at any level of passive smoke exposure. A dose-response relationship between passive smoke exposure and birth weight was not statistically significant. The relative risk of growth retardation by passive smoke exposure was also not significant.

\section{MULTIVARIATE ANALYSIS}

A multiple regression analysis of birth weight was conducted for mothers who had never smoked. Table $\mathrm{V}$ shows that passive smoke exposure was not significantly related to birth weight. Adjusted weight reduction from passive smoke exposure for two hours or more was $10.8 \mathrm{~g}$, which was nearly half of the crude weight reduction in table III. In another multiple regression analysis for all mothers, in which active and passive smoking were treated as continuous variables by using the number of cigarettes smoked per day and exposure time per day respectively, the adjusted weight reduction was $56.0 \mathrm{~g}$ for active smoking of 10 cigarettes per day.

A binary logistic regression analysis of growth retardation was conducted for mothers who had never smoked. No effect due to passive smoke exposure was observed, as shown in table VI. The adjusted relative risk was $1.0(95 \% \mathrm{CI}: 0 \cdot 7-1 \cdot 5)$ in mothers who had passive exposure for $2 \mathrm{~h}$ or more per day. This was almost the same as the crude relative risk in table III. When active smoking by mothers was included as an independent variable in the binary logistic regression analysis, the adjusted relative risk was $1.6(95 \% \mathrm{CI}: 0.9-2 \cdot 8$, $0.05<\mathrm{p}<0.10)$ for occasional and daily smokers.

\section{Discussion}

The present study showed a rather small effect due to passive smoke exposure on fetal growth. It is difficult to account for the results in terms of selection bias or recall bias. Study subjects were pregnant women who received perinatal care from obstetricians. As almost all deliveries in Aichi Prefecture were attended by physicians $(98.2 \%$ in a 1987 official report), there was little chance of selection bias due to medical care. The present study covers about one third of all deliveries in Aichi Prefecture during the study period. This may not be enough to warrant a generality from the study results, but we do not think that the results can be explained by selection bias. Subjects interviewed after delivery may have been influenced in their responses by the delivery outcome. However, we would expect that where low birth weight or growth retardation had
Table $V$ Multiple linear regression analysis on birth weight in mothers who had never smoked; $n=5336$. Infants with gestational age less than 37 weeks excluded. The mean and modal values were substituted for 115 cases with missing data for factors

Table VI Binary logistic regression analysis of growth retardation in mothers who had never smoked; $n=5336$. Infants with gestational age less than 37 weeks excluded. The mean and modal values were substituted for 115 cases with missing data for factors

\begin{tabular}{|c|c|c|c|c|}
\hline Factors & (Unit) & Coefficients & (SEM) & $T$ values \\
\hline $\begin{array}{l}\text { Passive smoking } \\
\text { Age } \\
\text { Parity } \\
\text { Height } \\
\text { Alcohol } \\
\text { Occupation } \\
\text { Gestation age }\end{array}$ & $\begin{array}{l}\left({ }^{0}<2 \mathrm{~h},{ }^{1} \geqslant 2 \mathrm{~h}\right) \\
\text { (years) } \\
\left({ }^{\text {nulliparous, }}{ }^{1} \text { parous) }\right. \\
\text { (cm) } \\
\left({ }_{\text {never, }}{ }^{1} \text { stopped, }{ }^{2} \text { occasionally, }{ }^{3} \text { every day) }\right. \\
\left({ }^{0} \text { never, }{ }^{1} \text { stopped, }{ }^{2} \text { continued or started) }\right. \\
\text { (weeks) }\end{array}$ & $\begin{array}{r}-10 \cdot 755 \\
7.070 \\
111.902 \\
12.589 \\
-0.938 \\
-3 \cdot 148 \\
101.657\end{array}$ & $\begin{array}{r}(10.914) \\
(1.448) \\
(11.591) \\
(1.041) \\
(6.857) \\
(6.247) \\
(4.251)\end{array}$ & $\begin{array}{c}0.99 \\
4 \cdot 88 \dagger \\
9 \cdot 65 \dagger \\
12 \cdot 09 \dagger \\
0 \cdot 14 \\
0 \cdot 50 \\
23 \cdot 92 \dagger\end{array}$ \\
\hline
\end{tabular}

Constant $=3045 \cdot 8$

$R^{2}=0.38$

$+p<0.01$

\begin{tabular}{|c|c|c|c|c|}
\hline Factor & (Risk category) & $\begin{array}{l}\text { Coefficient } \\
(\beta)\end{array}$ & $\begin{array}{l}\text { Adjusted } \\
R R\end{array}$ & $95 \% C I$ \\
\hline $\begin{array}{l}\text { Passive smoking } \\
\text { Age } \\
\text { Parity } \\
\text { Height } \\
\text { Alcohol } \\
\text { Occupation } \\
\text { Gestation }\end{array}$ & $\begin{array}{l}\text { ( } 2 \mathrm{~h} \text { or more) } \\
\text { ( } 35 \text { years or more) } \\
\text { (nulliparous) } \\
\text { ( } 154 \text { cm or less) } \\
\text { (drank every day/occasionally) } \\
\text { (continued/started) } \\
\text { ( } 38 \text { weeks or less) }\end{array}$ & $\begin{array}{r}0.034 \\
-0 \cdot 175 \\
0.720 \\
0 \cdot 752 \\
0 \cdot 111 \\
-0.156 \\
1 \cdot 715\end{array}$ & $\begin{array}{l}1 \cdot 0 \\
0 \cdot 8 \\
2 \cdot 1 \dagger \\
2 \cdot 1 \dagger \\
1 \cdot 1 \\
0 \cdot 9 \\
5 \cdot 6 \dagger\end{array}$ & $\begin{array}{l}0 \cdot 7-1 \cdot 5 \\
0 \cdot 4-1 \cdot 8 \\
1 \cdot 5-2 \cdot 9 \\
1 \cdot 5-3 \cdot 0 \\
0 \cdot 7-1 \cdot 8 \\
0 \cdot 6-1 \cdot 3 \\
4 \cdot 0-7 \cdot 8\end{array}$ \\
\hline
\end{tabular}

$\mathbf{R R}=$ relative risk

$95 \% \mathrm{CI}=\mathrm{EXP}(\beta \pm 1.96 \mathrm{SEM})$

$t \mathrm{p}<0.01$ 
occurred, subjects would tend to overstate rather than understate their exposure to passive smoke. This would cause an apparent increase in the effect of passive smoke exposure and so could not explain the rather small effect observed in the present study.

The crude effect of passive smoke exposure on birth weight reduction was found to be statistically significant, but the effect was eliminated by adjustment for confounding factors. Multivariate analysis of birth weight showed significant effects of parity and age (table V). These factors were also significantly associated with passive smoke exposure. Therefore the observed crude effect can probably be explained by the younger age at birth and the higher proportion of first deliveries for passively exposed mothers (table I).

Many previous studies investigated the effect of passive smoking on fetal growth in terms of paternal smoking habits. In the present study, women were asked the average duration of passive exposure to cigarette smoke each day at home, the work place, and other places, in addition to the smoking status of their husbands. Cross tabulation of these two indices revealed that about $30 \%$ of the women with husbands who smoked daily reported no passive exposure at all at home, and that $13 \%$ of the women with non-smoking husbands reported passive exposure at home. Some husbands probably refrain from smoking at home for the health of their pregnant wife and unborn child, and some pregnant women must be exposed to cigarette smoke at home from persons other than their husbands. These results suggest that an estimation of passive exposure using only paternal smoking involves a sizable miscalculation. Furthermore, about one third of the total passive exposure time was at the work place. These results suggest that the paternal smoking habit may be an inadequate index of maternal passive exposure to cigarette smoke.

Some of the previous studies included babies from preterm deliveries in their examinations of babies with low birth weight. The present study excluded babies with a gestation age of less than 37 weeks, because it was difficult to be certain whether the lower birth weight of these babies was due to growth retardation or shorter gestation periods, and because of confounding factors such as pregnancy complications which may be related to premature birth.

The results of the present study suggest that maternal passive smoke exposure has a small effect on fetal growth. Adjusted weight reduction from passive exposure for $2 \mathrm{~h}$ or more was $10.8 \mathrm{~g}$, which was equivalent to the adjusted reduction from active smoking of two cigarettes per day, and the adjusted relative risk of growth retardation from passive exposure for $2 \mathrm{~h}$ or more was almost unity. A biochemical assay study of passive smoking in the general population in Japan showed that urinary cotinine concentration for non-smokers living with heavy smokers who consumed more than 40 cigarettes per day was nearly identical to that for smokers of less than three cigarettes per day. ${ }^{3}$

A recent study in the USA reported an adjusted weight reduction of $24 \mathrm{~g}$ and an adjusted relative risk of growth retardation of $2 \cdot 2$ for full term deliveries by non-smoking mothers who had passive smoke exposure of $2 \mathrm{~h}$ or more per day. ${ }^{12}$ These values are higher than the corresponding values of $10.8 \mathrm{~g}$ and 1.0 , respectively, in the present study. Another recent study, from Denmark, showed much stronger effect of passive smoking; mean birth weight in non-smoking mothers was reduced by $120 \mathrm{~g}$ per pack of cigarettes smoked per day by the father. ${ }^{11}$

Some part of the smaller effects of passive smoking in the present study and other studies in Japan ${ }^{16}$ and China ${ }^{14}$ might be attributed to lower concentrations of carbon monoxide and nicotine in cigarette smoke which is inhaled by pregnant women. Japanese women may be more conscious about health maintenance during pregnancy than women in Western countries, perhaps through traditional Asian sociocultural norms which put a special pressure on women of reproductive age to maintain good health. The prevalence of smoking and alcohol drinking was only $5.6 \%$ and $15^{\circ}$ in the present study. This is far lower than $32 \%$ and $69 \%$ respectively in the American study, ${ }^{12}$ and $40 \%$ and $59 \%$ respectively in the Danish study. ${ }^{11}$ The rate of passive smoke exposure for $2 \mathrm{~h}$ or more per day was $35 \%$ in the present study, which is lower than $44 \%$ in the USA, ${ }^{12}$ contrary to the high prevalence of young adult male smokers in Japan. In addition it was found in the present study that about $61 \%$ of smoking mothers had stopped smoking by about 8 weeks of gestation, and that about $30 \%$ of women living with a smoking husband reported no passive smoke exposure at home. These findings suggests a stronger health consciousness in Japanese pregnant women.

The actual amount of passive exposure may be related not only to exposure time, but also to the concentration of the residual smoke in a room, which is dependent on ventilation, room size, building materials, number of persons smoking, and smoking behaviour. As these conditions may be different among countries, an international comparative study using biochemical marker assays of passive smoke exposure for pregnant women is needed.

Although this study did not show a significant effect of passive exposure on fetal growth, it is expected from our results that heavy exposure does induce a reduction in fetal growth, just as active smoking does. Therefore passive smoking of pregnant women is an important public health issue, especially in Japan where the prevalence of cigarette smokers among young adults is high.

We are grateful to the members of the Aichi Prefectural Society of Obstetricians and Gynaecologists for their cooperation with this research.

1 US Department of Health, Education, and Welfare Smoking and health: a report of the Surgeon General. Washington DC: US PHS, 1979, DHEW Publication No. (PHS) 79-50066.

2 Abel EL. Smoking during pregnancy: a review of effects on growth and development of offspring. Hum Biol 1980; 52 593-625.

3 Matsukura S, Taminato T, Kitano N, et al. Effects of environmental tobacco smoke on urinary cotinine excretion in nonsmokers: evidence for passive smoking. $N$ Engl $f M e d$ 1984; 311: 828-32.

4 Feyerabend $C$, Higenbottom T, Russell MAH. Nicotine concentrations in urine and saliva of smokers and nonsmokers. $B M \mathcal{F}$ 1982; 284: 1002-4.

5 Andresen $\mathrm{BD}, \mathrm{Ng} \mathrm{KJ}$, Iams JD, Bianchine JR. Cotinine in amniotic fluids from passive smokers. Lancet 1982 ; i: $791-2$. 
6 Smith N, Austen J, Rolles, CJ. Tertiary smoking by the fetus. Lancet 1982; i: 1252 .

7 fetus. Lancet 1982; i: 1252 . MacMahon B, Alpert M, Salber EJ. Infant weight and
parental smoking habits. Am $\mathcal{F}$ Epidemiol 1966; 82:247-61. parental smoking habits. Am $\mathcal{F}$ Epidemiol 1966; 82: 247-61. mortality. Am $f$ Obstet Gynecol 1967; 98: 708-18.

mortality. Am f Obstet Gynecol 1967; 98: 708-18.

Underwood PB, Kesler KF, O'Lane JM, Callagan DA. Parental smoking empirically related

10 Yerushalmy J. The relationship of parents' cigarette smoking to outcome of pregnancy: implications as to the problem of inferring causation from observed associations. Am f Epidemiol 1971; 93: 443-56.

11 Rubin HD, Krasilnikoff PA, Leventhal JM, Berget A. Effect of passive smoking on birth-weight. Lancet 1986; ii: 415-7.

12 Martin TR, Bracken MB. Association of low birth weight with passive smoke exposure in pregnancy. Am $\mathcal{f}$ Epidemiol 1986; 124: 633-42.
13 Haddow JE, Knight, GJ, Palomaki, GE, McCarthy JE. Second-trimester serum cotinine levels in nonsmokers in recond-trimester serum cotinine levels in nonsmokers in 481-4.

14 Chen Y, Pederson LL and Lefcoe NM. Passive smoking and low birthweight. Lancet 1989; ii: 54-5.

15 Statistics Bureau, Management and Coordination Agency. 1985 Population census of fapan, vol 3. Results of the second basic complete tabulation, Part 1. Tokyo: Nippon Tokei Kyokai, 1987.

16 Nakamura $M$, Ohshima A, Hiyama, $T$, et al. A study on the effect of passive smoking on pregnancy. Kosei No Shihyo 1988; 35: 23-30 (In Japanese).

17 Dixon WJ ed. BMD biomedical computer programs. Berkeley, CA: University of California Press, 1970.

18 Cox DR. The analysis of binary data. London: Chapman and Hall, 1970. 